\title{
The "Library of America" and the Welter of American Books . Wayne Franklin
}

\author{
... I fear I must leave the dinner table \\ hastily-if someone will show me \\ where the vomitorium is.
}

Lewis Mumford ${ }^{1}$

THE IMAGE OF A MAN as serious as Lewis Mumford publicly heading for the "vomitorium" can belong only to the modern year of wonders, nineteen-hundred-and-sixty-eight. But it was not the Chicago horror show or the real horrors of Vietnam that sent Mumford into his bilious vaudeville routine on the pages of the New York Review of Books that spring. Instead, it was the apprehension, which now seems a bit quaint against the larger violence of the era, that a preacher of freedom like Ralph Waldo Emerson was being incarcerated within the cruel gridwork of modern scholarly editing. Mumford argued that Emerson's latest editors, impelled by a pseudo-scientific literalism, were subjecting their victim to "ruthless typographic mutilation," thus pushing him out of reach of the ordinary reader. It was not just a jail the editors prepared for him after his torture: it was a "concentration camp" of apparatus, a compound marked by "technological extravagance and human destitution."

It was a time of extravagant public rhetoric and almost instantaneous fight-picking, whatever the topic, and the bitter tone Mumford chose for his review of the Harvard edition of Emerson's Journals soon was matched by the answering anger of those whom he had attacked. It would be hard, on the basis of style alone, to distinguish the little literary war which ensued on the pages of the Review from those more overtly political ones which then were raging, in adjacent columns, on the Vietnam debacle of President Johnson, the connivance of Vice-president Humphrey in it, the atrocities of Mayor Daley's "gestapo," and the like. But it would be wrong to see Mumford's eruption, or the other ones which it caused in friend and foe alike, as merely a spillage of those polluted social waters into the heretofore more genteel literary arena.

For one thing, Mumford had good reason to be angry. He was simple enough to believe that books had been made for reading, and reading by 
the most general of audiences. In the case of the Emerson Journals, so marred in the present edition by typographic squiggles inserted all over the pages to indicate the most minute changes in the evolution of the "text," it in effect was left to readers to perform the real task of editing as they labored to decipher not Emerson but Emerson's clarifiers. What one wanted was a clean page, honest in its regard for the process of composition, but honest, too, in acknowledging the use to which books (not "texts") were to be put. If literary works were to suffer at the hands of literary scholars who had so little sense of the humane, then whither art?

Mumford did overstate for the sake of scoring some of his hits. The Journals of course had not been published in Emerson's life, and they thus had never been prepared for the press by their author. Editing such items arguably involves steps which are almost always unnecessary and inappropriate in the case of published books or even manuscripts that bear the final changes of the author. Besides, as William M. Gibson noted in one of the letters responding to Mumford, Harvard already had made plans to issue a selected reader's edition of the larger Emerson project, in clean text, once the scholarly volumes were in print. Then director of the Center for Editions of American Authors, the body which set and enforced standards for such enterprises as the Emerson edition, Gibson also tried to argue that the Center's policy was in most regards in agreement with Mumford's criticisms. All of its new editions of works first published in their author's life thus would appear in clean (or "clear") text. Furthermore, the CEAA editions would be made available to commercial publishers at modest fees, so that popular reprintings might appear within a couple years of the scholarly volumes. Hence the general reader eventually would be well served by the scholars.

But the fight would not go away. At least one academic sincerely thanked Mumford for his defense of humane values, and others conceded here and there a bit of territory. For the most part, however, the brush fire which flared up on several occasions from January to May showed little graciousness and less candor. Nor was all the acrimony on the academy's side. In March, Edmund Wilson published a brief letter in support of Mumford's salvo. It was a letter so undisguised in its scorn for the academy that the academy's own deepening bitterness on the general issues raised by Mumford probably was to owe more to Wilson's intercession on Mumford's behalf than to Mumford himself. Yet Wilson's assault merely carried out 
to its articulate end a suspicion lurking already in Mumford's complaint. It thus became Wilson's war, and he was soon waging it with great passion, carrying it by year's end well into the heart of the enemy's country.

The apprehension which drove Wilson's campaign was of such long standing with him that it had assumed by 1968 a kind of tough maturity. It had become true by then, he wrote in his March letter, that the "editing of the classical American writers [had] got to be an academic racket that [was] coming between these writers and the public to which they ought to be accessible."3 On its surface, this was simply another sounding of Mumford's call for the ordinary reader to be kept clearly in mind. Of special pertinence in a democratic society, this was indeed a call which Wilson did issue, not only during the 1968 war but also at many other points in his career. In this particular case, however, Wilson was less concerned with the cluttered gracelessness (and unreadability) of scholarly editions than with the impertinence which allowed their editors to take over, and run according to what must have been very dull lights, the business of literary art. What Wilson was attacking in the person of those editors was not so much the specific products of their labor, or the wrong thinking which he (and Mumford) traced there, but rather the vast institutional shift in the world of letters which had put such people increasingly into positions of power, making of them a new class of cultural middlemen. It was not the ruling wisdom of these particular middlemen that bothered Wilson so much as the fact that there were any middlemen at all.

The last of our men of letters in the older, broad sense of that term, Edmund Wilson was a voracious reader as well as a prolific writer, and in his many critical essays he typically did not hesitate to rest his judgments on what pleased or displeased him in a given book. This lack of a pretense to mere objectivity continues to give much of Wilson's criticism an admirable note of fresh honesty, a note especially prounounced because even at his least agreeable Wilson never failed to see that reading is an act of life, an engagement rather than a dalliance. Even when one feels that he strayed in a certain opinion, one usually can admire the clarity and tenacity of his error. Cantankerous he might be, but never dull.

Of the professional reader - the academician, as distinct from the paid reviewer or essayist-Wilson entertained a rather low opinion through much of his career. It is not hard to imagine why. The rise of academic 
literary study, and later of academic training in creative writing itself, left Wilson and others of his generation filling a public function which gradually lost its currency as time passed. As with so much else in Western culture since the eighteenth century, reading and writing probably were fated to undergo some such rationalization. Taken over by a selfperpetuating class of scholars who were insulated from direct public exchange and scrutiny (and who hence tended to substitute shoptalk for general discussion), these human activities could not easily remain natural acts, acts of life enabled by common training, when in every other domain of experience-from agriculture to politics - the traditional was being reduced, through analysis, to the systematic. Wilson hardly was a natural man or a natural reader: college-educated, always alert to wide shifts of thought and behavior in his lifetime, insistently international in sympathy, no respecter of disciplinary preserves but neither a dilettante nor a sceptical American pragmatist untouched by theory, he brought to bear on his reading of literary works a familiarity with intellectual and artistic culture few similarly situated individuals could match. Yet he had the gift - or the acquisition - of a style which gave to his discussion of reading and books a decidedly public tone. Urbane without seeming learned and without being chic in the least, Wilson's critical prose was accessible and defiantly ordinary. It was in this sense the product of a democratic culture, of American culture as a whole rather than of those particular highbrow institutions with which Wilson was affiliated, be they the Hill School or Princeton, Vanity Fair or the whole avant-garde world of New York City. Wilson always wrote, that is, for the "general reader."

Not so the academician. In his first reaction to the issues raised by Mumford's 1968 review, Wilson excoriated "these stupid academic editions," which were prime evidence, he thought, of the "lack of taste and discrimination that [had] come largely to dominate the academic field of American literature." It was not just the editors, either, who bothered him. In $A$ Piece of My Mind (1956), Wilson found tastelessness, too, in the "dreary 'exposition des textes" that had become even by then "a kind of standard academic product." 5 To Wilson's mind, in scholarly editing or academic criticism one could find the same mass production techniques as were employed in the operations of the Ford Motor Company-essentially, the academy was a factory churning out inferior goods. In a 1970 essay on Richard Harris Barham, the once popular Victorian author, Wilson re- 
counted how he greeted with enthusiasm the news that Barham, whom he remembered as a special favorite of his own youth, had been the subject of a new biography. Unfortunately, that book proved to be "a dampening disappointment." Since its author was "a conventional professor," what else could he produce but "a typical product of the American acądemic mill"? It was a task that had been undertaken not out of love or even mere curiosity but rather because it was "an available academic job, not hitherto performed by anyone else, which would earn academic credit." In keeping with the requirements of its form, the pages of the book were "almost. always ankle-deep, and sometimes up to their necks, in footnotes" - notes which, like "much of the text," recorded "facts of no interest whatsoever." For was it not, Wilson asked in another piece written in the same year, the function of "fat footnotes" to be "laid down as a stratum at the bottom of the pages to meet the requirements demanded of an academic job"?? Like assembly line workers, for so Wilson's imagery again implies, such professors turn to their work with little pride, and what they make bears almost no sign of craft or intelligence.

"For whom, one asks," wrote Wilson in his Barham essay, "is such a book written? For what market has it been produced?" It was a "book for nobody," a perfect example of the academic thesis - a piece of labor intended for "no identifiable public," and of use only for advancing its author's academic reputation. ${ }^{8}$

No wonder that Wilson found the academy no welcome associate in the making, or the making accessible, of American literature. If the ruling canons of critical thought inside its walls promoted so little clarity or grace, and enforced so dismally a set of dead restrictions whose net effect was to make even truth uninteresting, then what might happen were the academy to aspire to-and actually to secure-some more public measure of control in literary affairs? It was not just that Wilson, so superb a craftsman in his own use of language, and so responsive to good language in others, felt offended by the sloppy and boring English which too often may leak, like bad oil, from the ordinary English teacher. Certainly he did feel so offended-offended enough, in fact, that he once proposed to entrust the teaching of English in the United States (or at least in the better schools) to a cadre of imported, certified Englishmen!9 More profoundly, he was rankled by the deadening task-and-reward system of the universities, a system which regulated work by creating (largely meaningless) 
"jobs" and then, by behavioral pressures, creating the jobbers to do them-or else. Not that there were not hacks enough in the real world, and grub streets of such number and aggregate length that, placed end-toend, they might reach from Madison Avenue to Hollywood and Vine. But at least such people and such establishments did not pretend that what they were doing was done in the interest of Culture. By contrast, the academic hacks claimed to be serving such a lofty cause when, all too often, they didn't understand what culture was. Nor did they have even the small snappiness of the worldly hacks - the talent for at least aiming what they wrote at some actual audience, if only to make a buck.

If the scholars' own books were unreadable, then woe to the classics given them to edit, since they might be expected to make the best of books as unreadable as possible, too. That, Mumford claimed, was precisely what had occurred in the case of Emerson: "Thus these Journals have now performed current American scholarship's ultimate homage to a writer of genius: they have made him unreadable." Worse yet, when Mumford had expressed his doubts in private to an academic friend, he was told not to review the Journals, since he was not himself an Emerson specialist and he would simply make "a gratuitous nuisance" of himself by speaking out. ${ }^{10}$

The issue at last became one of access. When, later in 1968, Wilson took up the fight from Mumford, he hammered away at this point over and over again. But his conduct of the battle was complicated from the start by the fact that he viewed the academic editions sponsored by the CEAA and its parent organization, the Modern Language Association, as intrusions of an even more personal sort on his own rights. While those editions might be lambasted strictly on their merits, it also was true that their funding - Wilson thought and claimed in print - had come from the wreck of a project dear to his heart.

What Wilson proposed doing, he was writing to associates as early as 1961, was to secure support for an American equivalent of the Pléiade series of Gallimard. He envisioned a handsomely printed run of the complete works of the major American authors, complemented by selections from the lesser ones. Already in his March letter to the New York Review, just as the Mumford controversy was getting underway, Wilson let it be known that his project had been scuttled so that the academics might set about their mutilations of the American classics. This was not, though, 
his first mention of the idea in print. That had come five years earlier, in The Cold War and the Income Tax (1963), where he described the proposal in some detail, claiming that he had been toying with it since the Second World War. ${ }^{11}$ Only in the early sixties, when the new Kennedy administration lent some of its brief glamour to the arts, did Wilson begin to mobilize broad support. Among his fellow enthusiasts at the time were Jacques Barzun, W. H. Auden, Allen Tate, Lionel Trilling, and Robert Penn Warren. Jason Epstein, then a young editor at a New York publishing house, tried to interest the Bollingen Foundation in the project. Because of restrictions on the uses to which Bollingen funds could be put, however, support was not forthcoming from that quarter. Somewhat later, Wilson explained in the first of his two attacks on the Modern Language Association in the New York Review, funds for his undertaking apparently had been set aside by the National Endowment for the Humanities shortly after its establishment in 1965. The next he knew, Wilson added, the MLA somehow diverted those funds to its own project, a project which had been defined (so its "fruits" were making clear by the late sixties) in a manner as antithetical as possible to his own. Where he wanted to make inaccessible books available again, cheaply, quickly, but elegantly, the MLA-CEAA enterprise would be making a few books available for the scholastic fraternity, at high cost, with intolerable delays, and with little grace.

Wilson ascribed to the chicanery of the literary profession in general, expecially as that was organized in its "employment agency" (the MLA), the virtual theft of the money promised to his idea. He characterized the bulk of the heavy, ill-made, almost indecipherable volumes coming with agonizing slowness from the MLA-CEAA plant as of interest to only a "very small group of monomaniac bibliographers"-probably the same fraternity responsible for preparing the volumes in the first place. Furthermore, he traced the blame for this literary disaster to the profoundly ill-advised imitation of Germanic models which had made of American higher education an "atrocity" that ought to have been ditched completely, as so many other German influences had been, during World War I. As it was, "The indiscriminate greed for this literary garbage on the part of the universities," Wilson added, "is a sign of the academic pedantry on which American Lit. has been stranded." 12 
Some of the shrillness of these claims is merely an index of the rage Wilson felt over the outmaneuvering he had suffered. But a much deeper question motivated him as well, and it made the public wrangling of 1968 into an ultimately serious clash over the future of literary culture in the United States. The issue concerned what, precisely, made up the body of any book. Of course Wilson recognized, as it would be absurd not to, that if one had a choice between good texts and bad texts it made sense to choose the best of them. Yet he also thought that availability was a crucial factor in the health of a literary culture, and that it was better to have a flawed text than none at all - the latter eventuality being what might, in many ways, come from the CEAA endeavors. Here Wilson was arguing from the uses of literature as public property, rather than from those arcane principles that guided the worst of the academic editions, which in effect served not to spread the word but rather to conceal it. But Wilson mixed with this essentially democratic awareness a more nearly professional concern as well. Like any writer who lives by his pen, Wilson knew precisely how much compromise is involved in the production of any published work. He thus appreciated the extent to which the "author" of a work is, except in the most rare of cases, in fact a composite of writer, editor, and publisher, among others. This was an insight lost on too many of the academics, who labored under the exaggerated ideal of authorship that had flourished in the romantic era. Books, Wilson instinctively knew, had untidy histories not merely because mistakes were made in printing them, or because publishers enforced changes which the suffering authors did not really want: they had untidy histories, too, because, like the medium out of which they were composed, they had a common lineage that the romantic notion of authorship tended to obscure. While you could hope to reproduce books in a form as near to that which the author approved as was reasonably possible, you could not hope to rationalize any text so as to make it certain and secure. When Wilson himself set the terms for the eventual publication of his journals, he made it clear (says Leon Edel) that there was to be "no scholarly apparatus and in particular no treatment of his text as if it were sacrosanct." The editor, Edel himself in the case of The Thirties, was to silently correct slips of the pen without distracting the reader by blocking the flow of the text with "the inevitable sic."13

One is probably right in believing that Wilson's care over his own last things owed a good deal to what he had learned in 1968. He had had a fair 
amount of experience in editing long before then, especially in his work on Fitzgerald's The Crack-up (1945), and the tactful role he had played in that instance was basically what he hoped for at the hands of anyone who might edit something of his own. He certainly had a good deal of anxiety about falling into the wrong hands, as he told Arthur Mizener in a letter written while he was at work on the Fitzgerald project: "I almost never read variants, and I believe that the publication and comparison of the various drafts of a writer's work is mostly perfectly futile. I have a horror of having my own production circulate in a state of undress, and for this reason have always avoided reading other people's work in the same condition." The "chips and shavings" of an author's workshop belonged for the most part on the "dump heap," he added to Mizener. He had no objection to leaving a few samples to demonstrate the development of a work as it passed through its different stages. But if too much were left, he warned, it would be "likely to be edited or written about in theses by scholars in universities who ought to be occupied with something better." 14 Hence, when the manuscript of The Waste Land, long considered lost, turned up in a private collection in the late sixties, Wilson's prediction came true, the "pump of the Eliot industry" being newly primed by its publication. Most of the gibberish spawned by the event would have been better left unsaid - one would say unthought, too, except that it obviously had not been thought in the first place - for it certainly did not help one understand in any noticeable way the poem as it had been revised and published by Eliot, with Pound's help, in 1922. A slightly different state of affairs existed in the case of Hemingway's Islands in the Stream when it appeared posthumously, edited by Hemingway's widow. Here was a work left unfinished at the author's death, a work of some interest: surely it deserved to be read-but read, Wilson stressed, in a form which its editor might give it. "The author is not to be charged with the defects of manuscripts which he did not choose to publish and for which he can now take no responsibility, nor his editors with making those works more coherent if the editing has been done with good judgment." 15 This was a position to which Wilson was long loyal, a position which bore the marks of a lifetime passed in the presence of literary culture, in the give-and-take of the publishing world, and in the full possession of a human and humane sensibility. 
From the start of the war which Mumford and Wilson launched in 1968 there was the unfortunate fact that the wrong provocation became its rallying point. The Journals of poor Emerson were, after all, an exception to the rule among the CEAA editions, and over the years since then the various ventures supported by the Center have added a good deal to the availability of sound and basically quite readable texts for the study of American literature. At the same time, many of the strictures voiced by Wilson against the early fruits of the projects have had some effect on the direction taken by later editors. Thoreau's works, issued by Princeton, have been presented in a format which is among the most attractive ever used for the writings of any American. They, and the volumes in other series issued by other university presses, have come out, it is true, with excruciating slowness - there was an eleven-year hiatus in the Melville project, for instance - but once they have appeared they in general have helped to foster the further reading of American works at home and abroad.

While these CEAA volumes were slowly being added to library shelves, an effort was begun to revive Wilson's competing idea for an American Pléiade, and in the spring of 1982 there appeared the first four volumes in this new venture. Funded (finally) by the National Endowment for the Humanities, and by the Ford Foundation, the Library of America promises to do all that Wilson had hoped for in his best imaginings. With luck, it may even be able to do much more.

The main movers behind the Library have been Daniel Aaron, Richard Poirier, and Jason Epstein. Cheryl Hurley, formerly of the MLA main office, has been serving as the executive director. Supporting her and the small staff under her is an array of textual advisors and trustees (including Robert Coles, Irving Howe, Nathan Huggins, Eudora Welty, and C. Vann Woodward), and the editors of the individual volumes, who include - to pick only from among those responsible for volumes already issued-Roy Harvey Pearce (Nathaniel Hawthorne), Kathryn Kish Sklar (Harriet Beecher Stowe), Justin Kaplan (Walt Whitman), Joel Porte (Ralph Waldo Emerson), and G. Thomas Tanselle (Herman Melville). Published in groups of four each spring and fall, the volumes so far have included, in addition to the writers just named, the following: Henry Adams, Henry James, Jack London, Francis Parkman, Mark Twain, William Dean Howells, Washington Irving, Edgar Allan Poe, Stephen Crane, and Thomas Jefferson. Plans for the long term call for filling out 
the sets for many of these authors as well as for adding to the list such others as William Faulkner, James Fenimore Cooper, William James, and Benjamin Franklin. And-so Daniel Aaron has suggested - "any architect, philosopher, naturalist, traveler, social thinker, historian, theologian, [or] scientist" who has produced works of "genuine literary merit," one day might qualify for inclusion, in some form, in the venture, which may be expected to run to over a hundred volumes before the century is out. ${ }^{16}$

Printed on fine paper, from type (or rather its "photocomposition" substitute) exceptional for both design and size, and in a format which is pleasant and practical at once, the books coming forth in their little seasonal ranks deserve all the praise which good bookmaking aimed at real use should receive. Although they run to between one thousand and fifteen hundred pages, and contain on each of those thinly margined pages a great deal of print, the books individually fit the hand well and invite not labor but delight from their readers. They will lie flat open without damage to their spines, are handsomely covered with an assortment of richly colored cloths, and have bound in their backs those old-fashioned ribbon markers now generally found, except here, only in bibles. Single volumes can hold so much in so compact a space that all of Parkman's histories, heretofore available only in hard-to-find old sets that could fill a desk top, fit into the two volumes devoted to him.

The editors of the individual volumes, like good ushers once they have seen their charges to a seat, retreat with little ado to take care of a few necessary chores, out of sight and almost out of hearing, in the rear. There are no introductions: these, argues Aaron, date too quickly for use in a series intended to be permanent - and the paper used in the Library will last long enough for William Faulkner to have become, before the pages disintegrate, merely another "early" American author. Modest chronologies, a note on texts, and (where necessary) trim notes to clarify things not clear from context or not generally known-not the sludge to which Wilson objected in scholarly editions, sinking the page bottoms in a morass of pointless learning-occupy a few leaves at the back of each volume. Opulent in their physical production, yet extremely readable, the books are models of authorial abundance and editorial restraint. Books, Edmund Wilson would have said, as books should be.

There can be little doubt that the Library of America realizes Wilson's 
vision with more care than he might have thought possible. Ironically but rightly, it uses wherever possible those very MLA-CEAA texts by which Wilson was so testily provoked, sans apparatus, but derived (as the Jack London ones have been) from the arguably best versions published during the author's life. In cases where new, better texts become available in the future, the Library volumes can be revised so as to take advantage of the change. The same sorts of revisions presumably can be introduced in instances in which, over time, shifts of taste may consign some previously included text to relative unimportance, or bring some previously overlooked ones into more prominent position. Some changes, in response to reviews, already have been scheduled so as to refine the present volumes even more.

The reviews have been almost uniformly enthusiastic. This is largely as it should be, since Wilson's idea had much merit and its vitality has been not only revived but even increased by the manner in which Aaron and his associates have acted upon it. Yet it is the very accuracy of their labors, as judged against Wilson's proposition, that should cause us now-almost twenty-five years after Wilson first actively pursued the notion - to consider the larger impact which the project is sure to have on the reading and studying of American literature over the decades to come. For the Library of America is inarguably the single most important publishing venture in the history of American literature. It not only dwarfs all previous "collections" of American writing, whether of national or regional scope: it makes available, both for private readers and for public institutions (here and overseas), American writers as they simply have never before been available. As such, it testifies to the new maturity which, since World War II, has developed in American literary culture. And it also suggests that we may expect from the future an even greater coherence in the writing - not just the reading - of American works, since once a canon of past authors has been fixed with some surety and their works have been made widely available and widely known, the sense of a tradition (even among writers so anti-traditional as modern Americans may seem at times) will subtly permeate the literary world.

When Wilson first broached the topic to Jason Epstein in 1961, however, the ruling conception of American literature was in many ways quite different from what it is today. The final test for any American work at that time was not whether it fit in a significant manner into the larger 
body of American writing, but rather whether it could stand up against the European, which in most cases meant English, competition. Literature was thought to have been established in the United States by the direct importation, during the nineteenth century, of suitable Old World models: it was the writer's function to adapt those models, with some modest attention to American local color, so as to produce works which might (other things being equal) have been written by a European. So strong was the grip of this deferent attitude on the American imagination that, as the careers of Pound and Eliot suggest, literature was presumed by even the most astute of its practitioners to be geographically conditioned, with the inevitable consequence that one might become a famous American writer best of all by leaving America.

How burdened with the lingering habits of colonialism this view of the literary situation in America was, the counterexample of William Carlos Williams might make clear. For Williams made art not only in but also out of the land which Pound and Eliot left, and he did so precisely by reaching back to the least European of all his American predecessors, Walt Whitman. And it now seems increasingly clear, forty years after the end of the Second World War, that the Whitman-Williams model will prove to be the important one not only for American poets but for many British (and many non-English) ones in our age as well. Furthermore, what enabled Whitman to shatter the metrics of the English past, and to create his line out of the mere equality of detail, was his willingness to follow out in language the radical drift of American political experiment. The language itself, of course, had been imported; but the line was assembled from it according to ideas of truly native growth.

All of this may suggest how unlikely Whitman's presence in a Library of America issued, say, in 1910, would have been. And that likelihood may in turn lead us to speculate on the ways in which the Library now being published (and planned) will embody, as it inevitably must, the current unspoken assumptions about literature (and American literature), assumptions which will date as time passes, until we will find it hard to imagine how they ever could have been believed in. Not, as pointed out above, that the new venture is immutable. It doubtless will grow over the years, and the plans now being entertained for various thematic volumes - of nineteenth-century poetry, of fugitive slave materials, of voyages and travels, and the like-will give to this pale masculine gathering of wor- 
thies, one may hope, a greater human depth and texture, so that in a decade at most the promise of the Library's name will be more accurately fulfilled. (At one point, the venture was going to be called "Literary Classics of America," which is still the corporate name under which the project is run. The change, as R. W. B. Lewis wrote in his review of the first volumes, was a "strategic" one ${ }^{17}$-it also pointed toward a less rigidly highbrow notion of what "literature" is, and that, too, is a hopeful sign.)

In 1961, it remained possible to think of a literary tradition in the exalted terms employed, say, by Eliot in "Tradition and the Individual Talent" - the writers of a culture being, in Eliot's vision there, a kind of club whose social relations will change, ever so slightly, every time a new member is inducted. In the main, though, the vast number of potential members simply never get in, so that the changes do not occur with great frequency, and they are not large in scale when they do occur. After the sixties and seventies, however, literature in America has been notably democratized - not only contemporary literature, but the literature of the past as read in the present as well. We have come to see that the striving for expression, however infelicitous the expression itself may be from a strictly literary viewpoint, is an inseparable part of the American social experiment, an exercise in which group after group that has arrived on these shores has taken part. This is to say that "literature" is to a large degree an artificial category, a sorting device by means of which the great mass of books in essence is kept out of the hands of the great mass of readers. There always are more books published than make their way into libraries; there are always more books in libraries than are seriously discussed in the literary circles of the country; there always are more books discussed than survive to become of permanent importance.

This is as it should be, as it must be, of course. But the chance at every point in this sifting for exclusions to be made according to quite nefarious principles is much too high for us to feel happy with the actual workings of the pattern. Censorship almost always has been of less importance in this country than have more hidden exclusionary means. The virtual extinction of all the emigrant languages, for instance, came about because the dominant language group in the United States controlled the major publishing centers, and by social pressures rather than political ones - though political ones there have always been-simply did not let enough nonEnglish material through to keep the traditions of the Welsh or the Nor- 
wegians or the Germans or the others alive. The ethnic presses which such groups did set up (like the press established by the Cherokees in Georgia in the 1820s) had little chance to survive against the forces moving the population toward mono-lingualism. Even today, among scholars, the dominance which was achieved by the English-speaking peoples in the United States in the nineteenth century (and then again in the twentieth, for the fight has been largely a modern one) is taken as an unspoken warrant for ignoring almost wholesale the rich ethnic heritage of the era before that hegemony at last was secured. The Dutch of New Netherland, the Swedes of the Delaware Bay, the Spanish of Florida and the Southwest, the French of the northern fringes and of the heartland: they all left, if not literary masterpieces (a modern concept in any case), at least a verbal imprint of which, if we believe in the virtues of a truly pluralistic society, we should at least be cognizant. And there are the more severe losses, too, those which came about because whole groups of people - most blacks and Indians, and many whites, women and men alike, too-have been accorded only silence.

So far as I have been able to discover, the Library of America has failed to take to heart the lessons of the literary renaissance of the past two decades, which has begun to move us into these deeper waters of American writing. Talk about a W. E. B. Du Bois volume represents, for all the welcome that should be given to the idea, merely another example of the sort of strategic move seen in the inclusion of Harriet Beecher Stowe among the first four writers represented in the Library. The problem with the Library as it so far has been presented is that its inherently European notion of literary art is profoundly at odds with the study of American writing as that study has been evolving since Wilson initially took up the cause. For in the country at the present it is not the old narrow category of literature but rather the broader, more humane one of writing which seems on the ascendent. A surge of interest in American autobiographies and memoirs, for instance, has given us some of the best new reading from the American past, reading which satisfies the national fascination with pragmatic affairs at the same time that it reveals with uncanny detail the reliance which Americans, in their struggle for self-definition, have placed on language. For all that one can tell from the Library, that exciting extension of American reading habits might never have occurred-indeed, basically didn't occur. 
One should expect to wait, of course, for plans of such grand sweep to realize themselves completely. The problem in the meantime, however, is that the Library will become a subtle but powerful determinant of American reading habits as well as an apparently neutral servant of literary culture. The presence of a given author in the Library will give a kind of imprimatur to that author. Worse yet, the absence of any author from the Library will tend to deny access to that author, and to deny access in a way rather more forceful than - were there no Library, but only librariesotherwise would have been true. As more is included in the Library over the years, furthermore, the continued absence of any figure from it will tend to make that figure progressively more obscure, especially if (as seems promised by the directors of the Library) the major writers will come first, followed by the minor ones, who will be followed by the thematic volumes mentioned earlier. Likewise, to the extent that Henry James (for instance) is given coverage in eight large volumes, the problem of what one does with a writer of major importance but slim production, such as (to take a quite pertinent example) Kate Chopin, becomes especially difficult. Because the volume format chosen for the venture is so rigidly insistent on a certain amount of bulk, writers who measure up in one sense may not in another-just as, to digress for a moment, Whitman's long line keeps being cut off in the volume devoted to him, or the inclusion of the map in the Jefferson volume (such maps being, it should be noted, far from rare in so space-conscious a tradition of writing as ours) created tough design challenges for the Library. We need a more sublty graded system in these physical matters as in questions of editorial choice: not a mere switch marked "in" or "out" but rather a means of recognizing the many kinds of merit and the many sorts of appeal which the writing of a truly democratic culture will display. So far, the only real hint of a wider vision in the Library of America can be found in the surprisingly full inclusion of Jack London, whose social writings (such as John Barleycorn and The People of the Abyss) are especially welcome. But the same exclusionary slogan which we may imagine being employed to keep less celebrated writers out of the Library - "genuine literary merit"- easily might have kept London out as well. "Genuineness" in any case entails a whole series of judgments, many of which are not literary at all: besides, can one imagine "literary merit" that is not by definition "genuine"?

It is the potential influence of the Library which gives even to its praise- 
worthy aspects certain troubling implications. Wilson found most objectionable in American bookmaking the lack of that elegance which he associated with French (and, more generally, European) publishing. Perhaps because of his socialist background, Wilson in effect was objecting to the admittedly sloppy, unregulated, at times downright sleazy conditions of the American book trade. Whatever the particular reasons for his disgust with those "gigantic [and] unattractive" American books that "come apart while you are reading them," as he fumed while researching Patriotic Gore, what he really was wishing for was a more tidy company of volumes, a company which could give to the welter of American literature some more genteel, not to say elite, European order. ${ }^{18}$

But it is precisely the welter of books, the actual odd volumes, in a kaleidoscope of colors and a positive wealth of physical disagreements, which represents the vigor of American writing, and that is a vigor which such an undertaking as the Library of America, perhaps by definition, cannot capture. American writing exists in just such a sloppy manner in the world, often quite unpleasant from a bookmaker's or booklover's tasteful perspective, but often with life enough to make up for its awkwardness. And when one sets about seeking to bring to that welter some centralized control and some agreement as to the essentials - as both the MLA-CEAA projects and the Library of America seek to do, the latter even more actively than the former-one is invariably going to leave out of the final product a good deal of the original flavor. Had the standards which Wilson wished to impose on the old American books actually been in force at the time most of them first appeared, the vast majority of them never would have been published because the resources to meet those standards simply would have been lacking. I, for one, would much prefer having the Narrative of William Wells Brown, An American Slave or the Memoirs of Harriet Newell (an American missionary to India) or the Life and Adventures of A-No. 1, America's Most Celebrated Tramp in their original modest editions, with thick type and yellowing paper, sans any real element of "design," to having nothing but silence in their stead. I likewise find paperback reissues of such fugitive works far more important for what they now make reavailable than objectionable for their own relative lack of flair as physical objects. Indeed, the scorn for paperbacks as a class, which Wilson had and which the Library of America people seem to share, strikes me as so profoundly opposed to the whole argument in favor of access - since it was 
the paperback which democratized reading (and not just American reading) in this century - that, were they to have their way, it would be on the hard rock of high-priced hardbacks (among which, for the vast majority of Americans, the Library's volumes certainly are to be placed) that American Lit., as Wilson had it, would be "stranded." No one need feel ashamed that the best writing from the American past - the best from a literary viewpoint or from a more broadly humane one - has so often had a cheap exterior. All the more do the bright interiors illuminate the mind and heart. The great variety of type faces, page sizes, paper textures, and the like, which one is likely to encounter in reading one's way through the great library of America that actually exists in the scatter of shelves and boxes, bookstores and even garage sales of this country - this is, as well, part of the means by which, once pried free from the thin upperclass of Europe, verbal power began to make itself an essential part of the best experiments yet launched in the New World.

As for hermeticism, I prefer the kind that deals with inner matters, affairs of the spirit, to that which tries to counter the sly means by which the dirt of this earth violates our human will. We need to remember what really matters. Perhaps as it ceases to be a new venture and assumes the status of an institution, the Library of America will become the shadow not of the one man who envisioned it but rather of the people-all the people-in whose name his vision came to him. Unless it so evolves, it shall have lost its chance to nourish American writing and American culture, not just to safely embalm them.

\section{Notes}

1. Letter to the Editor, The New York Review of Books, 10:10 (May 23, 1968), p. 43.

2. The New York Review of Books, 10:1 (January 18, 1968), p. 4.

3. Letter to the editor, The New York Review of Books, 10:5 (March 14, 1968), p. 35.

4. ibid.

5. A Piece of My Mind (New York: Farrar, Straus and Cudahy, 1956), p. 164.

6. The Devils and Canon Barham (New York: Farrar, Straus and Giroux, 1973), pp. 5-6.

7. The Devils and Canon Barham, p. 49.

8. The Devils and Canon Barham, p. 6.

9. A Piece of My Mind, pp. 161, 163.

10. The New York Review of Books, 10:1 (January 18, 1968), p. 4. 
11. The Cold War and the Income Tax (New York: Farrar, Straus and Company, 1963), pp. 52-58.

12. The New York Review of Books, $11: 5$ (September 26, 1968), pp. 8, 10.

13. The Thirties, ed. Leon Edel (New York: Farrar, Straus and Giroux, 1980), p. xi.

14. Letters on Literature and Politics, ed. Elena Wilson (New York: Farrar, Straus and Giroux, 1977), p. 689.

15. The Devils and Canon Barham, pp. 113, 111.

16. The Texas Humanist, 6:5 (May/June, 1984), p. 43.

17. The New Republic, May 19, 1982, p. 26.

18. Letters on Literature and Politics, p. 683. 